\title{
Distributional Status of the Diversity of Phytoplankton Population in Fresh Water Lake
}

\author{
K. Rajyalaxmi, "M. Aruna
}

Department of Botany, Telangana University, Dichpally, Nizamabad, Telangana, India

\begin{abstract}
Phytoplanktons are primitive, usually aquatic, photosynthetic and delightful organisms in their diversity and efficacy. Phytoplankton comprises a well-organized system for trapping the solar energy. These miniature amaze ball phykos alone contribute $90 \%$ of the total oxygen produced by the plant kingdom. They are prime manufacturers in water ecology and play a crucial role in converting sewage and waste water into beneficial biomass. Most of the Phytoplanktons grow in different water bodies such as ponds, pools, ditches, lakes, reservoirs, rivers and oceans. But some of them are common and widespread in habitat of the soil surface layer wherever moisture and sunlight are available. The main aim of the present study was to explore the phytoplankton from Singabhupalem Lake, study the diversity pattern and assess quality of the lake. In the present study a total number of 75 taxa of fifty-three genera, thirty families and fifteen orders of phytoplankton belonged to four classes such as Chlorophyceae, Bacillariophyceae, Cyanophyceae and Euglenophyceae were recorded. The phytoplankton diversity study provided several new data with many of the phytoplankton taxa being recorded for the first time in study site, such as 32 taxa among the Chlorophyceae, 21 taxa of the Bacillariophyceae, 17 taxa of the Cyanophyceae and 5 taxa of the Euglenophyceae. The present observations revealed that Chlorophyceae species were dominant followed by Bacillariophyceae, Cyanophyceae and Euglenophyceae.
\end{abstract}

Keywords : Phytoplankton Diversity, Distributional Status and Singabhupalem Lake

\section{INTRODUCTION}

Phytoplankton are largely autotrophic organisms relying upon photosynthesis to convert light into chemical energy which is then stored in organic compounds. Photosynthesis in addition to carbon and light, requires both macro (e.g. $\mathrm{N}$ and $\mathrm{P}$ ) and micro nutrients (e.g. Fe and $\mathrm{Zn}$ ) in the environment. The rate of biomass production of an aquatic ecosystem mainly depends upon diversity of Phytoplanktons. Algae are involved in water pollution in a number of significant ways. Pollution may bring about an environment of the algal nutrients in water and this may selectively stimulate the growth of a few types, producing massive surface growths or "blooms" that in turn reduce the water quality and effect its use. Certain algae are to flourish in water polluted with organic wastes and to play an important role in "self purification" of the water. The selective type of algae that exists in polluted water also is being used as indicators of collection of animal drinking the water or living in it. Since algae constitute part of a chain of aquatic life in the water whatever alters the number and kinds of algae affects all of the other organisms, including fish. Thus it requires a continuous monitoring and study of algae existing in waters of 
various quality in order to determine what control, what changes or what uses be instituted for the benefit of man and for conservation of water and desirable aquatic life. The present lake was the important component of water system of Kothagudem area.

The term 'Water Quality' deals the physico-chemical and biological specification of water and directly or indirectly impacts the survival of aquatic species (Kohinoor, 2000). Natural environmental factors in aquatic ecosystem include various Physico-chemical characters of water such as colour, odor, $\mathrm{pH}$, temperature, DO, BOD and COD which is necessary for growth and abundance of Phytoplanktons. Phytoplankton members also act as indicators of water purity and quality because of their susceptibility and effectual response to changes in their neighbouring environment (Siddika, 2012).

\section{METHODS AND MATERIAL}

Study area: Conventionally accessibility of nutrients and sedimentation were considered as the main driving force of algal communities' aquatic ecosystem. In the present work an attempt what made to document the phytoplankton diversity. For the proposed work, the major irrigation fresh water lake was selected and their physico chemical parameters and biological analysis was completed. Selected lake, Singabhupalem is situated at Kothagudem area, Bhadradri Kothagudem district and Telangana state. Lake is geographically located at latitude $17^{0} 29^{1} 6^{11} \mathrm{~N}$ and longitude $80^{0} 33^{1} 13^{11} \mathrm{E}$. This is major fresh water lake which gets filled during rains. The lake was free from any shading and has sufficient sunlight throughout the day.

The size of the lake and their respective characteristics were shown in Table-1. Four stations were selected as shown in Table -2
Table 1: Morphometric characteristics of the Singabhupalem Lake

\begin{tabular}{|c|c|}
\hline Dimensions (m) & 280.0 X 320.0 \\
\hline Size (acres) & 15 acres \\
\hline Depth $(\mathrm{m})$ & $10 \mathrm{~m}$ \\
\hline Capacity $\left(\mathrm{m}^{3}\right)$ & 38321.8 \\
\hline
\end{tabular}

Table 2: List of Four Stations

\begin{tabular}{|c|c|}
\hline Station & Location \\
\hline Station-I & East \\
\hline Station-II & North \\
\hline Station-III & West \\
\hline Station-IV & South \\
\hline
\end{tabular}

Analytical methods and Techniques : Physicochemical and biological water quality was measured from the sample lake. Samples were taken from site once in a month between 6.00 a.m. to 9.00 a.m. for a period of 12 months from January to December 2017.

- On site analysis: On site analysis of temperature, $\mathrm{pH}$, Color, Odor were carried out at the standard protocols, methods and techniques of American public health association

- (APHA). Color by visible and odor by sensible method. The $\mathrm{pH}$ of the water sample was analyzed by using classical method at site and a digital $\mathrm{pH}$ meter at laboratory. The volume of water sample was taken after a couple of minutes to achieve a stabilizing reading. $\mathrm{PH}$ of solution is taken as logarithm of hydrogen ions, value ranging from 0 to 7 is acidic, 7 to 14 is alkaline, and value 7 is neutral. Mainly lake water $\mathrm{pH}$ range from 4.8 
to 8.5. $\mathrm{pH}$ was measured by using digital $\mathrm{pH}$ meter, temperature measured with mercury filled glass thermometer, transparency was measured with Secchi disk.

- Laboratory analysis : The chemical analyses were carried out by following the methods of APHA (1998) and CSIR (1974).

The present study was undertaken to elucidate phytoplankton diversity of selected lake in Kothagudem area with reference to water quality parameters. The main objective of this work is to study the distribution and diversity of Phytoplanktons in Singabhupalem Lake. For analysis of phytoplankton water samples were collected monthly wise (January to December 2017) from four stations (Station- I, II, III, \& IV) of selected lake. Collected samples were mixed thoroughly and taken $5 \mathrm{ml}$ in plankton chamber contain few drops of Lugol's solution. Lugol's solutions was used to enhance sedimentation of the Phytoplanktons and were fixed immediately with $4 \%$ formaldehyde which was used as a fixative agent, fixed phytoplankton samples were allowed to settle for 24 hours kept in laboratory and the supernatant was collected carefully for analysis. Phytoplankton species observed under Olympus Binocular microscope and identified by using standard plankton determination keys.

\section{RESULTS AND DISCUSSION}

Water quality parameters colour, odor, $\mathrm{pH}$, Temperature, DO, BOD and COD were measured and species were identified belonging to classes Chlorophyceae with 32 taxa, Bacillariophyceae with 21 taxa Cyanophyceae with 17 taxa and Euglenophyceae with 5 taxa ( Table -3). Distribution of Phytoplankton in four stations of Singabhupalem Lake is focused in Fig -1.

The water temperature varied from $21^{\circ} \mathrm{C}$ to $38^{\circ} \mathrm{C}$. the $\mathrm{pH}$ value varied from 7.0 to 8.5 in study period, the DO value ranged from $3.8 \mathrm{mg} / 1$ to $6.5 \mathrm{mg} / \mathrm{l}$, the biological oxygen demand varied from 5.8 to $13.6 \mathrm{mg} / \mathrm{l}$, while chemical oxygen demand values ranged from 0.1 to $1.1 \mathrm{mg} / \mathrm{l}$.

Table 3 : List of identified Phytoplankton species from four stations of Singabhupalem Lake during January December 2017 (No. Of Species per ml).

\begin{tabular}{|c|c|c|c|c|c|}
\hline \multirow{2}{*}{ Name of the Species } & \multicolumn{4}{|c|}{ January - December 2017} & \multirow[b]{2}{*}{ Total } \\
\hline & Station - I & Station -II & Station- III & Station-IV & \\
\hline \multicolumn{5}{|l|}{ Chlorophyceae } & \\
\hline Actinastrum gracillimum & 60 & 32 & 14 & 56 & 162 \\
\hline Ankistrodesmus spiralis & 11 & 35 & 12 & - & 58 \\
\hline Chara vulgaris & 59 & 65 & 34 & 52 & 210 \\
\hline Characeum ambiguum & 43 & 21 & 26 & 54 & 144 \\
\hline Chlamydomonas globosa & 21 & 32 & 23 & 21 & 97 \\
\hline Chlorella ellipsoidea & 28 & 24 & - & - & 52 \\
\hline C.vulgaris & 112 & 67 & 65 & 32 & 276 \\
\hline Cladophora oligoclona & 43 & 35 & 39 & 39 & 156 \\
\hline
\end{tabular}




\begin{tabular}{|c|c|c|c|c|c|}
\hline C. glomerata & 34 & 43 & 44 & 48 & 169 \\
\hline Closterium decorum & 65 & 54 & 56 & 65 & 240 \\
\hline C. dianae & 67 & 45 & 34 & 12 & 158 \\
\hline Coleochaete orbicularis & 36 & 35 & 41 & 34 & 146 \\
\hline Cosmarium portianum & 45 & 43 & 45 & 30 & 163 \\
\hline C. depressum & 43 & - & - & - & 43 \\
\hline C. exiguum & 46 & 38 & 34 & 54 & 172 \\
\hline Eudorina elegans & 26 & 24 & 22 & 15 & 87 \\
\hline Hydrodictyon reticulatum & 32 & 43 & 34 & 24 & 133 \\
\hline Oedogonium gigantium & 34 & 45 & 34 & 34 & 147 \\
\hline Padiastrum angulosum & 24 & 32 & 35 & 43 & 134 \\
\hline P.duplex & 28 & 38 & 34 & 16 & 116 \\
\hline P.simplex & 37 & 36 & 54 & 21 & 148 \\
\hline Pandorina morum & 32 & 26 & 15 & 11 & 84 \\
\hline P.cylindricum & 15 & 17 & 27 & 32 & 91 \\
\hline scenedesmus acuteformis & 42 & 58 & 98 & - & 198 \\
\hline S. denticulatus & 56 & 98 & 56 & - & 210 \\
\hline S. quadricauda & - & - & 32 & - & 32 \\
\hline Spirogyra crassa & 83 & 94 & 56 & 54 & 287 \\
\hline S. parvispora & 32 & 28 & 42 & 32 & 134 \\
\hline Tetraedron bifercatum & - & - & 35 & - & 35 \\
\hline Ulothrix Mcylindricum & 28 & 23 & 27 & 19 & 97 \\
\hline Volvox aureus & 54 & 123 & 24 & 32 & 233 \\
\hline Zygnema pectinatum & 43 & 28 & 58 & 43 & 172 \\
\hline Total & 1279 & 1282 & 1150 & 873 & 4584 \\
\hline \multicolumn{6}{|l|}{ Bacillariophyceae } \\
\hline Achnanthes inflata & - & 32 & 35 & - & 67 \\
\hline Amphora coffoeformis & 42 & 32 & 22 & - & 96 \\
\hline Cyclotella meneghiniana & 32 & 33 & 43 & 25 & 133 \\
\hline Cymbella aspera & 42 & 23 & 43 & - & 108 \\
\hline Eunotia camelus & - & - & - & 32 & 32 \\
\hline Fragillaria crotonensis & 32 & 54 & 21 & 23 & 130 \\
\hline Gamphonema constrictum & 25 & 34 & 56 & 31 & 146 \\
\hline Melosera granulata & 16 & - & - & - & 16 \\
\hline Navicula capitatoradiata & 54 & 26 & 42 & 32 & 154 \\
\hline N. cincta & 45 & 29 & 56 & - & 130 \\
\hline N. cryptocephala & 22 & 25 & 19 & 11 & 77 \\
\hline N. lanceolata & 32 & 23 & 12 & 24 & 91 \\
\hline Nitzschia denticula & 32 & 35 & 38 & - & 105 \\
\hline$N$. palea & 24 & 32 & 23 & - & 79 \\
\hline
\end{tabular}




\begin{tabular}{|c|c|c|c|c|c|}
\hline Pinnularia abaujensis & 32 & 23 & 25 & 23 & 103 \\
\hline P. acrosphaeria & 36 & 24 & - & - & 60 \\
\hline P. bravicostata & 21 & 21 & 21 & 12 & 75 \\
\hline P. graciloides & 17 & 24 & 16 & - & 57 \\
\hline Stauronensis anceps & 24 & 21 & 16 & - & 61 \\
\hline Synendra acus & 27 & 23 & 18 & - & 68 \\
\hline S. rumpens & 14 & 18 & 21 & - & 53 \\
\hline Total & 569 & 532 & 527 & 213 & 1841 \\
\hline \multicolumn{6}{|l|}{ Euglenophyceae } \\
\hline Euglena pascheri & 27 & 14 & 21 & 32 & 94 \\
\hline E. polymorpha & 23 & 11 & 21 & 12 & 67 \\
\hline E. Sanguinea & - & 18 & - & 23 & 41 \\
\hline Phacus orbicularis & 15 & 24 & 27 & 42 & 108 \\
\hline $\begin{array}{l}\text { Trachelomonas } \\
\text { acanthostoma }\end{array}$ & 23 & 17 & 19 & 22 & 81 \\
\hline Total & 88 & 84 & 88 & 131 & 391 \\
\hline \multicolumn{6}{|l|}{ Cyanophyceae } \\
\hline Anabaena iyengarii & 23 & 21 & 14 & - & 58 \\
\hline Aphanocapsa grevillei & 21 & 21 & 17 & 18 & 77 \\
\hline Chroococcus disperses & 23 & 25 & 21 & 21 & 90 \\
\hline C. minor & 23 & 23 & 20 & 12 & 78 \\
\hline Gloeocapsa atrata & 23 & 25 & 15 & - & 63 \\
\hline Gloeotrichia ghosei & 25 & - & 32 & 23 & 80 \\
\hline Hydrococcus rivularis & 16 & 24 & - & - & 40 \\
\hline Lyngbya majuscula & 23 & - & 13 & 15 & 51 \\
\hline Mycrocystis aeruginosa & 21 & 25 & 24 & - & 70 \\
\hline Nostoc muscorum & 22 & 21 & 15 & 9 & 67 \\
\hline Oscillatoria obtusa & 32 & 23 & 25 & 21 & 101 \\
\hline Phormidium molle & 19 & 21 & 17 & 18 & 75 \\
\hline Scytonema subtile & 13 & 9 & - & 23 & 45 \\
\hline Spirulina gigantea & 21 & 21 & 23 & 26 & 91 \\
\hline Stigonema turfaceum & 23 & 27 & 32 & 34 & 116 \\
\hline Tolyphothrix distorta & 26 & 32 & 23 & 26 & 107 \\
\hline Trichodesmium erythraeum & 23 & 18 & 16 & 21 & 78 \\
\hline Total & 377 & 336 & 307 & 267 & 1287 \\
\hline
\end{tabular}




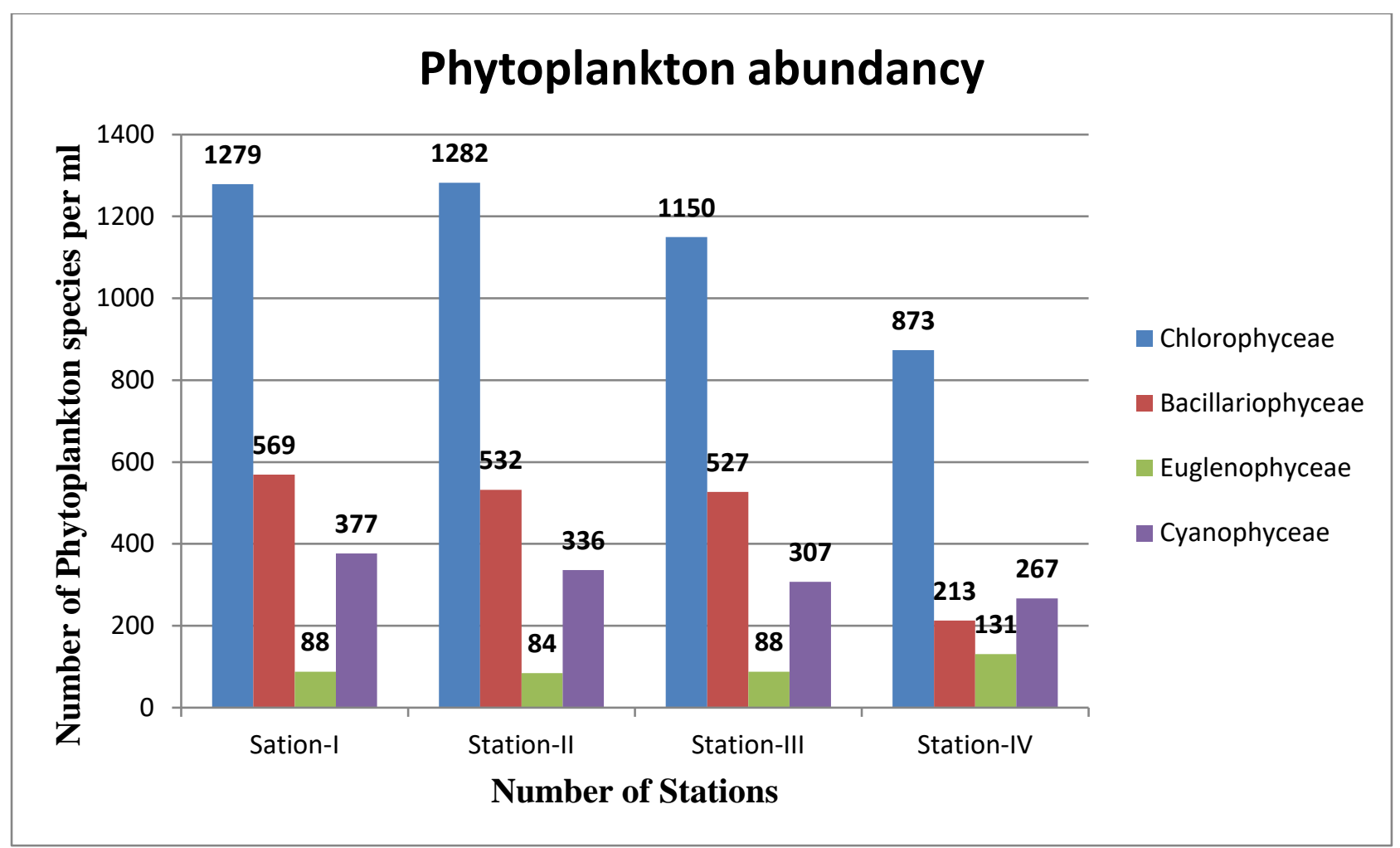

Figure 1. Distribution of Phytoplankton species in four stations of Singabhupalem Lake.

75 species of Phytoplankton belonging to 4 classes were identified from the four sites of lake during the study period. The largest class was Chlorophyceae represented 32 species, followed by Bacillariophyceae with 21 species, Cyanophyceae with 17 species and the least was Euglenophyceae contributing 5 species. Phytoplankton diversity richness was highest in Station-I and least in Station-IV. The Chlorophyceae members were most abundant, followed by Bacillariophyceae, Cyanophyceae and Euglenophyceae in all stations. The study reveals that the highest number of Chlorophyceae was recorded in Station-II, Bacillariophyceae and Cyanophyceae in Station-I and Euglenophyceae in Station-IV (Fig-1).

These Phytoplankton members show the levels of water quality in the aquatic environment as bio-indicators. And also indicate diversity and conservation of water. Observation of sample studies revealed that four groups of algae belongs to Chlorophyceae members were dominant followed by Bacillariophyceae, Cyanophyceae and Euglenophyceae. Similar observations were made by Earlier workers Ramesh and Aruna (2015), Shailaja and Aruna (2016) ,.Aruna et.al (2018) and Neha Srivastava (2018).

The present study, during January to December 2017 on phytoplankton diversity and water quality parameters data serves as a detailed report on the selected lake to establish objectives and approaches for purification and reclamation of Lake for future studies. Plate-1 \& 2 shows some of the identified taxa of phytoplankton from Singabhupalem Lake. 


\section{PLATE-1}

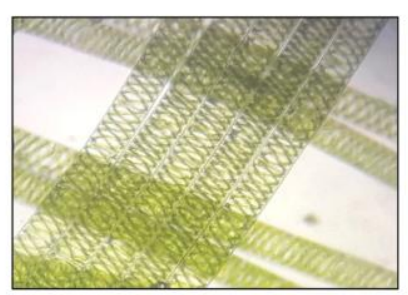

Spirogyra parvispora wood

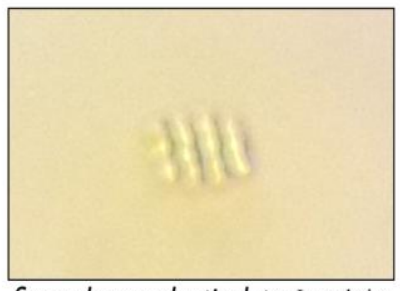

Scenedesmus denticulatus Lagerheim

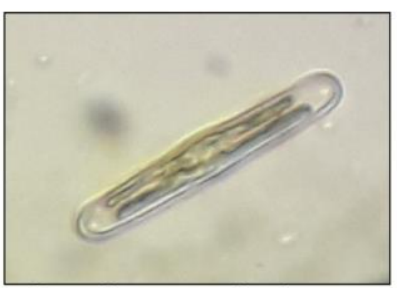

Pinnularia graciloids Hust

\section{PLATE-2}

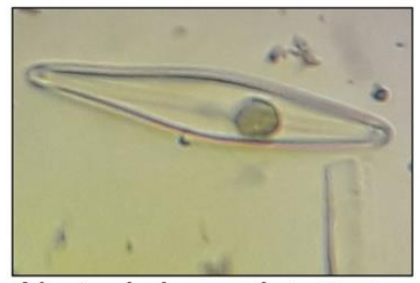

Navicula lanceolata Kuetz

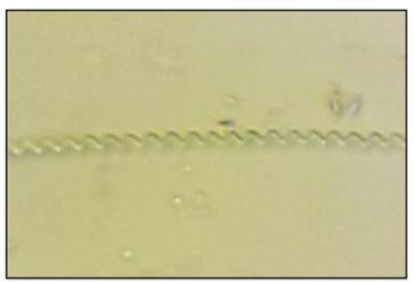

Spirulina gigantea Schmidle

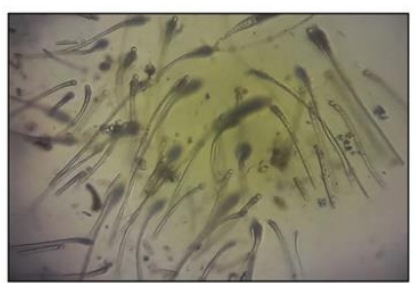

Gloeotrichia ghosei Singh

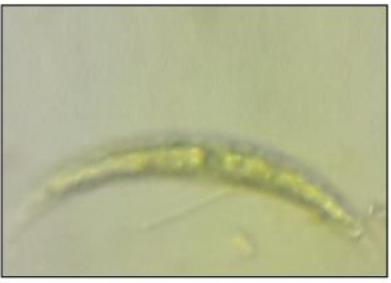

Closterium dianae Ralfs ex Ehren

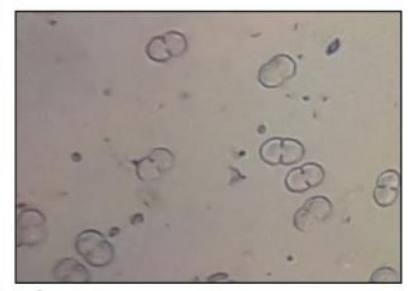

Cosmarium exiguuna W.Archer

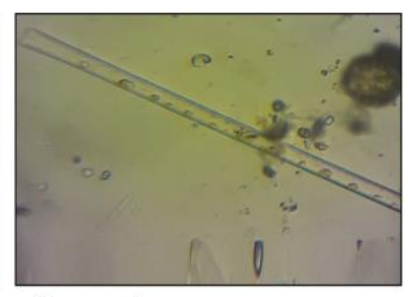

Synendra rumpens Kuetz

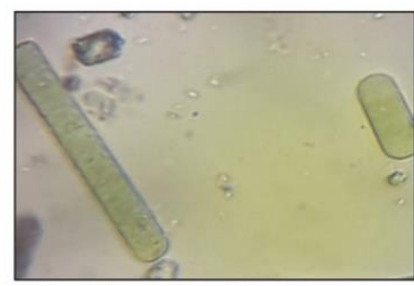

Oscillatoria obtusa Gardner

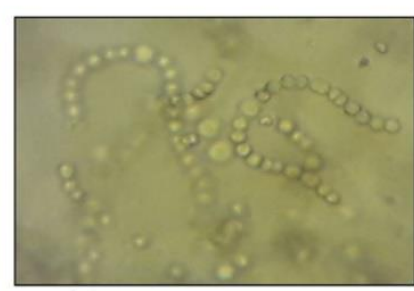

Nostoc muscorun Ag

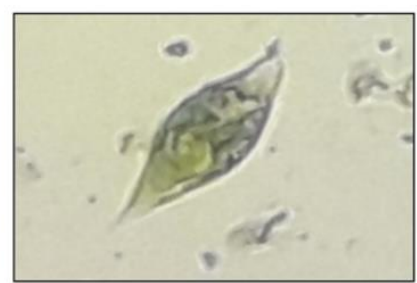

Euglena sanguinea Ehrenberg IV. CONCLUSION
The physicochemical characteristic of aquatic ecosystem is significantly influenced by the human activities and for this reason it directly affects the flora and fauna, which reside in water bodies. The present study analyzed physico-chemical and biological parameters of the Singabhupalem Lake. The result suggested that the Lake water is of good quality and presence of all constituents were within permissible limits without any toxicants and any possibilities of mixing sewage, agricultural wastes and industrial effluents.

\section{REFERENCES}

[1]. Ahmed, M.R. 1967. Algal flora of some ponds of Kanpur. Hydrobiology. 29: 156-164.

[2]. Anand, N. 1998. Indian freshwater microalgae. Bishen Sing Mahendrapal Singh, Dehradun, India publishers, p.94.

[3]. Aruna, M. et.al (2018). Diversity of Phytoplankton and Assessment of water in two lakes of Telangana state, India. International Journal of Scientific research in Science and Technology. 4 (10), 245-256.

[4]. Asha, M.S. (2015). Effect of Water Quality on Phytoplankton Abundance in Selected Ponds of Nedumangad Block Panchayat, Kerala. Emer Life Sci. Res. 1(2): 35-4

[5]. Das, S.M. and Srivastava, V.K.; 1956. Quantitative studies on freshwater plankton and hydrobiological factors. Indian J. Ecology, 10(6): 40-55.

[6]. Desikachary, T.V. 1959." Cyanophyta." Pub. By Indian Council Ed Agricultural Research.

[7]. Ekhalak Ansari, Mohini Gadhia, N.C. Ujjania (2015). Phytoplankton Diversity and Water Quality Assessment of ONGC Pond, Hazira. International Journal of Research in Environmental Science (IJRES) PP 1-5.

[8]. Fritsch F.E and Rich F (1913). A four years observation of fresh water pond (Barton Pond) near Harpended Ann Biolacust 6-83. 
[9]. Fritsch, F.E. 1935. The Structure and reproduction of the algae. Vol I. University Press

[10]. Iyengar MOP (1938). The vegetation of Madras and its enviorons in scientific survey of madras and its environs university madras $57-59$.

[11]. Iyengar MOP (1940). On the algal flora of some muddy rain water ponds Asst. Proc 27th Indian Science Congress, Madrass Poet III - 28. J. Environ. Biol. 27: 35-38.

[12]. Kozak, A., 2005. Seasonal changes occurring over four years in a reservoirs phytoplankton composition. Polish Journal of Environmental Studies, 14 (4): 451-465.

[13]. Mohammad M. J. Ecological Studies and Faunal Diversity of Wyra and Paler Reservoirs of Khammam District, Telangana, India, doctoral diss, Dept. Environmental studies, Acharya Nagrjuna University, Guntoor, Andhrapradesh,2015.

[14]. Neha Srivastava (2018). Fresh water algal diversity of Central India. International journal of research and development in Pharmacy and Life Sciences. 7 (4) 3039-3049. New Delhi.

[15]. Prescott, G.W. 1951. Algae of western great lake areas. Wm. C. Brown Co. Publishers Dubuque Iowa.

[16]. Ramesh, B. and Aruna, M. (2015). Diversity of Fresh water algae in Trivenisangamam of Nizamabad District, Telangan state. India. European journal of Botany, Plant sciences and Phytology. Vol. 2, No.4, pp 31-37.

[17]. Round F.E. (1970). Studies on bottom living algae in some lakes of the English lakes

[18]. Roy, K. (2014). Ecological Dynamics and Hydrobiological Correlations In Freshwater Ponds Recent Researches and Application. Int.J. Environ Biol. Universal Res. Publications. 4 (2):112-118.

[19]. Shailaja , A. and Aruna, M. (2016). Diversity of Phytoplankton in Agraharam Lake of Karimnagar District, Telangana State, India.
Life Sciences international research journal: Volume 3 pp 51-53.

[20]. Srivastava N, Suseela MR and Toppo K. (2014) Fresh water cyanobacteria of Sai River near Lucknow, Uttar Pradesh. Tropical Plant Research,: 1(2) 11-16.

[21]. Tiwari, A, Chauhan, SVS. (2006). Seasonal phytoplanktonic diversity of Kitham Lake, Agra.

\section{Cite this article as :}

K. Rajyalaxmi, M. Aruna, "Distributional Status of the Diversity of Phytoplankton Population in Fresh Water Lake", International Journal of Scientific Research in Science and Technology (IJSRST), Online ISSN : 2395-602X, Print ISSN : 2395-6011, Volume 6 Issue 1, pp. 227-234, January-February 2019.

Available at doi :

https://doi.org/10.32628/IJSRST196131

Journal URL : http://ijsrst.com/IJSRST196131 